\title{
Integrating Thematic Instruction using Webbed Curricula Model to Improve Students' Reading Comprehension on Informational Text
}

\author{
Ryan Dwi Puspita \\ IKIP Siliwangi, Indonesia, dwiryan531@gmail.com
}

Cecep Wahyu Hoerudin

Universitas Islam Negeri Sunan Gunung Djati, Indonesia, cecepwahyu@ uinsgd.ac.id

Rully Agung Yudiantara

Universitas Islam Negeri Sunan Gunung Djati, Indonesia, rully.agung@uinsgd.ac.id

\begin{abstract}
Webbed curricula model presents the concept to integrate various subjects in a learning process. It employs several activities that enable students to be capable of providing a meaningful learning and experience for them. This study was aimed at examining the effect of integrated thematic learning that refers to the model of webbed curricula to improve 5th grade students' reading comprehension skills on informational text. It used quasi experimental method and collected data through observation, pre-test and post-test. There were 368 samples of students participated in the study. The results indicated that integrating Thematic learning using the model of webbed curricula carried significant effect on improving students reading comprehension skills on informational text. It can be seen from the difference related to their ability to read before and after learning by using webbed curricula model. This research suggests that students reading comprehension should be supported by teaching materials, learning media, student worksheet and interesting and practical activities to stimulate their reading performance.
\end{abstract}

Keywords: informational text, thematic learning, reading comprehension, webbed curricula

\section{INTRODUCTION}

Reading skill is one of the language skills which is very important for language learners. This skill should be mastered by elementary school students to strive in their academic life. It provides them ability to read and acquire comprehension on a wide variety of texts, especially informational text provided in their textbooks. In addition, it will open broad opportunity for them to explore new world and allow them to gain new knowledge, enjoy literature, and perform daily activities that are an integral part of their life in the society. Reading comprehension has been the focus of the researchers in elementary school setting because of its crucial role in building students academic performance. Researchers have spent their effort in investigating the problem and solution in the context of reading comprehension in elementary school. Yochum (1991), Fox (2009), Sahin (2013), Croce (2014), Walters (2014) are researchers who in their studies found that some elementary school students had difficulty in reading comprehension, especially when it came to informational text. Their finding confirmed that problem of reading comprehension had can be associated with many different factors.

In Indonesian context, reading comprehension is a challenging task for students. Reading difficulties are experienced by elementary school student. This happens in many parts of Indonesia especially in Bandung regency, West Java. According to the report released by PISA, students performed in reading

Citation: Puspita, R. D., Hoerudin, C. W. \& Yudiantara, R. A. (2020). Integrating Thematic Instruction Using Webbed Curricula Model to Improve Students' Reading Comprehension on Informational Text. Anatolian Journal of Education, 5(2), 1-18. https://doi.org/10.29333/aje.2020.521a 
comprehension gained average score of reading ability which is still below the OECD country average performance. Their poor reading comprehension can be spotted in several areas namely: understanding paragraph ideas, reading graphs, understanding relationships between facts, relations of linguistic logic, and finding reading ideas (OECD, 2016).

Students' difficulties to deal with reading comprehension should be a primary concern for teachers. Their poor command in reading comprehension calls for swift action on the part of the teachers to improve their performance in the learning process. There are many possible efforts that can be proposed to solve this problem. The problem requires an active learning approach. This approach should be designed to boost students' reading comprehension in elementary school. The emphasis should be on active learning for students since they will receive advantages in their learning process. In line with this, Meyers \& Jones (1993) writes "Active learning involves providing opportunities for students to meaningfully talk and listen, write, read, and reflect on the content, ideas, issues, and concern of an academic subject". It implies that in active learning there is a focus shift from the teacher to students as a learning center. Students are expected to be active and engaged to be involved in designing learning material. Furthermore, students are in a position to refute the traditional roles as passive receptors. In contrast, they are expected to learn and practice how to learn knowledge and skills to be able to use them meaningfully.

\section{Integrated Thematic Learning}

Learning activity can be designed by teachers to achieve proper educational results. It should be done systematically by teachers when they are delivering material in the classroom. Given this expectation, teachers should plan carefully their mission and implement it gradually and regularly throughout their learning process. They also should consider learning as a whole by taking into account various components involved. In line with this, this study developed an integrated thematic instruction using Webbed model (ITIWM hereafter) to deliver reading comprehension learning in elementary school. ITIWM is considered to be one of the effective teaching models which caters and deals with students' emotional, physical, and academic dimension in an integrated manner. Several studies have reported thematic integrated instruction such as Munawaroh (2010), Masdiana, Budiarsa and Lamba (2014), Kristiantari (2014), Setyawan and Mustadi (2015), Hermawati, Al- Rasyid and Mujtahidin (2015), Waridah (2016), Setiawan, Sa'dijah and Sa'dun (2017). Their findings show that that integrated thematic instruction has proven effective to improve students' cognitive, affective and psychomotor abilities in an elementary school.

Several studies on integrated thematic instruction in Indonesian context have been conducted. Unfortunately, those studies have not addressed the use of webbed curriculum in the context of integrated thematic instruction. This is to say that the issue of ITIWM has not been discussed extensively among researchers especially in Indonesian context. The present study is aimed at investigating ITIWM to improve students' reading comprehension on informational text (SRCIT hereafter) for grade 5 in elementary school. The study used the term integrated thematic instruction which is adopted by Indonesian Curriculum in year 2013. Integrated Thematic Instruction (ITI) was first developed in the early 1970s. It refers to a learning model to implement a brain-friendly learning environment for students. It allows teachers to use themes throughout the year and organize curriculum content and skills to deliver to their students. It is implemented in learning because it has several advantages. It is compatible with students' brain and it is able to create an environment that will enhance their performance and provide the basis for a successful learning experience (Kovalik \& Olsen, 1994).

Historically, ITI approach was originally developed for students who meet the following criteria: gifted, talented, smart, and fast learners. It was designed to serve and meet their learning need which was not the same as their counterparts. It did not follow the conventional learning model which

Anatolian Journal of Education, October $2020 \bullet$ Vol.5, No.2 
requires students in early grades (grade 1 to 3 ) of the elementary school to learn in a segmented manner. The conventional learning model divides their subject and follows the existing scientific format. Using this learning model, students' knowledge and experience are segmented in line with the segments of the studied knowledge. As a result, students' knowledge and experience are fragmented and incomplete. This condition is against to the children development who still need holistic knowledge and experience.

ITI can be defined as learning activities that enable students both individually or in a group to explore and find holistic learning. It offers students learning models that make learning activities relevant and meaningful for them. It can take several forms namely formal, informal activities and active inquiry to facilitate students to acquire knowledge and facts. This is done by empowering their knowledge and experience to help them understand the world of their life (Kadir \& Asrohah, 2015). It is designed in order to improve learning outcomes by leveraging students' experience who have networks from various aspects of their lives and knowledge (Puspita, 2017).

An Integrated Thematic approach is endorsed by the 2013 curriculum in Indonesia. This approach is implemented by using a scientific approach. Scientific approach refers to a learning process designed in such a way that students actively construct concepts, laws or principles through some steps. The steps include observation stages (to identify and find problems), formulation of problems, proposal of hypotheses, collection of data with various techniques, data analysis, conclusions, and communication or presentation of the concepts, laws or principles found in learning (Pusat Pengembangan Pendidikan Kependidikan Kemdikbud, 2013).

Implementation of integrated thematic learning based on 2013 curriculum design can be seen in the following table:

Table 1

Curriculum 2013 Design

\begin{tabular}{|c|c|c|c|c|c|c|c|}
\hline $\mathrm{N}$ & Components & I & II & III & IV & $\mathrm{V}$ & VI \\
\hline \multirow{2}{*}{\multicolumn{8}{|c|}{ Group A }} \\
\hline & & & & & & & \\
\hline 1 & Religion Education & 4 & 4 & 4 & 4 & 4 & 4 \\
\hline 2 & PPKN (Civic Education) & 5 & 6 & 6 & 4 & 4 & 4 \\
\hline 3 & Indonesian Language & 8 & 8 & 10 & 7 & 7 & 7 \\
\hline 4 & Math & 5 & 6 & 6 & 6 & 6 & 6 \\
\hline 5 & Science & - & - & - & 3 & 3 & 3 \\
\hline \multirow[t]{2}{*}{6} & Social science & - & - & - & 3 & 3 & 3 \\
\hline & Group B & & & & & & \\
\hline 1 & Culture and Art & 4 & 4 & 4 & 5 & 5 & 5 \\
\hline \multirow[t]{2}{*}{2} & $\begin{array}{l}\text { Physic and Sport } \\
\text { Education }\end{array}$ & 4 & 4 & 4 & 4 & 4 & 4 \\
\hline & Total & 30 & 32 & 34 & 36 & 36 & 36 \\
\hline
\end{tabular}

Based on the above table description, it can be seen that subjects in group A are designed to emphasize students' competences both cognitive and affective. On the other hand, subject in group B are tailored to nurture both affective and psychomotor aspects. The curriculum integrates competence both IPA (science) and IPS (social science) where the similarities between the two exist. IPA and IPS contents are closely related to content of subjects like religion, civic education, Indonesia language, Math and Physical and sport education. This integration applies to class I, II and III elementary school. For higher class including class IV, V, VI the competence for IPA and IPS can stand alone and are integrated into the theme for class IV, V and VI. Learning activities are realized in learning hour for each week during the semester. In a week, learning hour for SD/MI (elementary school) class I, II, 
and III is 30, 32, and 34 hours respectively. For class IV, V and VI their learning hour in a week is 36 hours. Each learning hour lasts for 35 minutes in SD and MI.

\section{Webbed Curriculum Model}

This study applies Webbed curriculum model. Before curriculum 2013 was applied in Indonesian schools, the schools had applied curriculum called KTSP (Kurikulum Tingkat Satuan Pendidikan/ Educational Unit Level Curriculum). In its implementation, KTSP curriculum divides learning material into separate subject for each subject. The subject name used were Math, Science, Social science, civic education, Indonesia language, and Art. After the implementation of curriculum 2013, Indonesian elementary schools started to change. The schools start applying integrated theme model using webbed curriculum. One of its distinction is that this model is an integrated learning model that uses the theme as the basis of learning. This learning model combines multiple disciplines or subjects that are bound by one theme (Fogarty, 1991). Themes can be set by the teacher with students or fellow teachers. Once the theme is agreed upon then it should be developed into several selection of subthemes. In developing sub theme, it should be taken into account relationship among related subjects. With this in mind, the main theme should have a wide scope which cater the range of material and provide provision for students to learn more. The webbed model places more emphasis on student engagement in learning so that students can gain hands-on experience. Through direct experience students will eventually understand the concepts they have learned and can relate to other concepts.

Webbed model has some characteristics. One of them is that it emphasizes the students as a subject of learning on the one hand and teachers act as facilitators on the other hand by providing guidance to students to do learning activities. Using this model, students receive hands-on experience and immediate experience in learning. It allows students to be exposed to something tangible/ concrete as the basis for understanding more abstract things. It creates less clear separation among subjects that students learn and promotes learning which is directed to the discussion of the closest themes related to student life.

Webbed model presents the concept of various subjects for students in their learning process. It employs several activities that enable students to be capable of providing a meaningful learning and experience for students. It encourages students to be able to understand the concepts as a whole. Beyond classroom, this is necessary skill and knowledge to assist them in solving their problems daily. With this in mind, teachers should be able to link the teaching materials from one subject with other subjects, even relate the subject with the student's life and the state of the school environment where they are.

\section{Expected Students' Reading Comprehension Level}

Based on observation in several school, it was found that some student in grade five suffered difficulties to deal with reading comprehension especially on informational text. This was evident by their lack of competence to understand explicit meaning, understand important information, to apply information they comprehended, to analyze and to evaluate information by way of observation (listening and reading) and critically questioning based on their curiosity on themselves, God's creature, activities and object they found in their home, school, playground using logic and systematic language. Given this situation, the researcher designed and developed the learning media and material to improve students' reading comprehension skill for elementary school grade five. Then the researcher analyzed 2013 curriculum in terms of syllabus development, lesson plan and material for integrated thematic learning. The study included analysis on core competence, basic competence and indicators which could be developed to facilitate students to improve their reading comprehension on informational text. The researcher also analyzed material for integrated thematic learning which were 
adjusted to syllabus development and lesson plan, Finally researcher found theme which was relevant to be used as learning material which were in line with the 2013 curriculum using webbed model.

This study investigates students' reading comprehension. To be specific, the level of reading comprehension to be achieved in this research are: (1) literal understanding. It means that the reader must be able to recognize and remember the meaning expressed in the text. (2) reorganization. It refers to the reader's ability to analyze, synthesize or to reset information explicitly stated in the text; involves both quotations and summary and paraphrase. (3) an inferential understanding. This has something to do with reader ability to observe the relationship of information and then make conclusions. This conclusion is based on the relationship of causal relationship which is not directly expressed. (4) drawing conclusions and interpreting figurative language, and understanding the evaluation. It implies that the reader should be able to evaluate the information they comprehended. They synthesize the information and make the planning of various activities based on the information they comprehended (Hamra \& Syatriana, 2012).

\section{Informational Text and How to Learn it}

This study discusses informational text reading comprehension. Since their early childhood or period of their elementary school, children are expected to be information literate both information recognition and comprehension. As part of technological society, student is expected to be able to read and write not only in printed form but also in digital form. This is in line with the statement from Schmar - Dobler (2003) who states that students should be able to access internet, select and synthesize information. These skills are crucial for their future successful career and academic achievement (Jennings, Caldwell\&Lerner, 2006). Teaching students reading informational text is important because it is placed in a standardized test. Performance in the steps of the test can be used to evaluate students and too promote and accept students in their enrollment in several program and educational level. Informational text represents a large number of content in standardized test.

Type of informational text used in this study are texts related to social science, natural sciences and mathematics that use problem-solution patterns, problem discussion and then possible solution suggestion (Jennings, Caldwell \& Lerner, 2006). Informational text has been used in elementary school in many countries. Sulak \& Gunnes (2017) reported his study in Turkey. They explained that in 2005 , the curriculum asked teacher to deliver informational text to be taught with a thematic approach. On the part of the students, they began to explore various text structures in the narrative, informative, and poetry genres. Likewise, in Indonesia since the enactment of the Curriculum 2013, elementary school students are beginning to learn to use an integrated thematic approach. In learning to understand informational text, students are presented in advance with direct activities that will support SRCIT. They learn informational text using scientific method steps namely observing, asking, gathering information, analyzing data and communicating the result.

Scientific method is done in learning informational text. To get a clearer picture, this section is explaining in a glance its steps. In observation activities, students are stimulated by teachers to express their experiences related to the text. To do this, teacher shows some pictures related to the text discussed. Next step, question activities where teacher and students pose question and answer related to observations activities. the third step is information collection activities. In this step, students are assigned teachers to read the text of information that the teacher has designed so that in one of these activities the student is able to understand the science, social and Indonesian language content. Fourth step is data analysis. In this step the teacher assigns the students to answer the questions that have been provided both in the Student Worksheet created by the teacher. The worksheet is tailored in order student to achieve expected indicators in learning. Last step is finding communication. In this step, the teacher assigns students to deliver the results of data analysis that has been accomplished. In addition, 
the researchers provide students additional activities through real activities or experiments that must be done by students in relation with the text of information that they had studied.

To implement ITIWM, this study divided learning activities into three stages: first, what teachers should do before reading session, secondly, what teachers and students do during reading session, and third what the teacher do when text reading has been done (Wallace, 1992). When it comes to teaching reading comprehension, teachers have many opportunities to help students learn from textual content they are dealing with. They can guide students through several tasks which can be attributed to three distinct phases of reading activity: before reading, during reading, and after reading (Anders \& Lloyd, 1989: Mustafa, 1996).

This study is conducted to deal with the researchers' road map in the scope of reading comprehension for informational text in elementary school in Indonesia context. Previous studies that have been conducted by the researchers includes: Puspita research, et al (2017) related to development of integrated thematic instruction using materials, development of student Worksheet based on Know, Want to Know, Learn (KWL) strategies, and task design on integrated thematic instruction to improve reading comprehension in elementary school. To date there is a little research concerning ITIWM to improve SRCIT in Indonesian context. This may happen because in general, elementary school in Indonesia especially in upper classes apply Connected Curriculum model. This study tries to fill in the gap by proposing to implement ITIWM to improve SRCIT in elementary school in Bandung regency. To be specific, this study was aimed at investigating students' reading comprehension for several subjects including science, social, Mathematics and Indonesian language. It addressed the following research questions: 1) What is the effect of ITIWM on SRCIT? 2) How is ITIWM implemented in reading comprehension class?

\section{METHOD}

\section{Research Design}

The study applied quasi-experimental method. The design used in this research was Non-Equivalent Groups Design (NEGD). It used Pretest-Postest design with control group. There were nine classes serving as experimental class $(\mathrm{N}=259)$ and three classes acting as control class $(\mathrm{N}=109)$. This research was conducted in elementary schools located in Bandung regency, Indonesia. The population in this study involved all 5th graders of elementary school with their average age from 10 to 11 years old. Samples of the study were taken at a random basis with students having easy access to information was taken into consideration.

This study was aimed at testing the differences in the results of 5th grade elementary school learning between pretest and posttest through quantitative assessment, as well as comparing student learning outcomes based on control class and experimental class. In the final validation process, this study conducted descriptive statistical analysis through the test of normality, Homogeneity and Hypothesis testing. These steps were taken to achieve the goal of measuring the extent of the effect of ITIWM to improve SRCIT of 5 th grade.

\section{Participants}

The samples of this study were eight classes of 5 th grade and were taken from the following schools: Sekolah Dasar Muhammadiyah, Madrasah Ibtidaiyah Miftahul Jannah, Madrasah Ibtidaiyah YPAI, Madrasah Ibtidaiyah YUPPI, Sekolah Dasar Negeri Simpang Baru, Sekolah Dasar Sekarwangi, Sekolah Dasar Junti Girang 04, Sekolah Dasar Negeri Junti Girang 03, Sekolah Dasar Warungcaringin. In a nutshell, there were 368 students and 8 teachers participating in this study. This study was conducted in nine elementary schools located in Bandung regency, Indonesia. The reasons to select them are: 
1. Researcher lives in Bandung

2. Researcher $\mathrm{PhD}$ program is on early childhood education with emphasis on language teaching

3. Local government suggestion related to selection of these samples for study

4. Reading comprehension level that is expected to improve refers to reading comprehension level for learning. This objective can be applied to grade 5 in elementary school. Sampling technique was conducted by selecting schools with easy information access category, school with medium ease of information access and school with difficult access to information category. School with easy access of information refers to schools located in the city and they are accredited A. Meanwhile, medium access of information category refers to schools in the process of transition to achieve accreditation A. School with difficult access of information refers to schools located in the rural areas and they are accredited B. Control and experiment groups were taken from each school category that is class A and B. unlike other schools, SD Warungcaringin had only one class for grade five and this study used other class from other school to serve as control group. The treatment given to experiment class was in the form of teaching reading comprehension using syllabus development, lesson plan for webbed model learning. In contrast, control group received similar webbed model but the model was not developed and their syllabus and lesson plan and assessment were not developed. The research was conducted in the odd semester of 2016/2017 academic year of 5th grade elementary school. There were some aspect taken into consideration to determine the sample of this research namely: (1) input from academic experts and educational practitioners, (2) school location are in Bandung regency (3) differences in access to information (4) some selected schools have implemented the 2013 curriculum, (5) the unavailability of ITIWM for reading comprehension in these 5th grade elementary schools.

\section{Data Collection}

Existing condition of student learning reading comprehension in these nine elementary schools in Bandung regency was obtained through interviews and observation. The study also collected data on the effect of ITIWM on SRCIT through pretest and posttes. Those data were analyzed quantitatively using t-test.

\section{Measurement}

Reading comprehension test: The test question was given to the students to measure their informational text comprehension level after students were treated using ITIWM. The test was constructed using 11 questions in the form of essays that must be accomplished by students. This question was given when students had accomplished reading and reviewed the informational text. Additional task in the form of essays were also given in the form of Student Worksheets that were separate from teaching materials. The question in the worksheet consisted 3 items. This essay must be accomplished before they follow reading activity of informational text.

Assessment Instrument was compatible with the guidelines from assessment process stated in Curriculum 2013. It was developed from previous study conducted in 2017 for assessing informational text reading comprehension. It also passed the Judgment of three experts. These experts belonged to learning model, child's language education specialist and the curriculum expert fields.

To assess student competence, this study applied ten indicators using 11 questions. This can be explained in detail in the following table: 
Table 2

Test Item

\begin{tabular}{|c|c|c|c|c|c|c|}
\hline \multirow[t]{2}{*}{ No } & \multirow{2}{*}{$\begin{array}{l}\text { Indicators for reading } \\
\text { comprehension }\end{array}$} & \multirow[t]{2}{*}{ Test item } & \multicolumn{4}{|c|}{ Score } \\
\hline & & & 1 & 2 & 3 & 4 \\
\hline 1 & $\begin{array}{l}\text { Students are able to understand } \\
\text { the meaning in relation to its } \\
\text { usage in the text. }\end{array}$ & $\begin{array}{l}\text { Apa yang dimaksud dengan kata "inspirasi" pada paragraf kedua } \\
\text { teks yang kamu baca? (What does the word "inspiration" mean } \\
\text { in paragraph that you read?) }\end{array}$ & & & & \\
\hline 2 & $\begin{array}{l}\text { Students are able to recognize } \\
\text { the relationship among parts in } \\
\text { the paragraph of the text }\end{array}$ & $\begin{array}{l}\text { Tuliskan informasi penting dari paragraf } 1 \text { dan paragraf } 2 \text { dari } \\
\text { teks yang kamu baca!(write important information that you find } \\
\text { in paragraph one and two) }\end{array}$ & & & & \\
\hline 3 & $\begin{array}{l}\text { Students are able to express } \\
\text { main ideas found in the text. }\end{array}$ & $\begin{array}{l}\text { Tentukan pokok pikiran dari paragraf } 3 \text { dan paragraf } 6 \text { ! (decide } \\
\text { the main idea found in paragraph three and six!) }\end{array}$ & & & & \\
\hline 4 & $\begin{array}{l}\text { Students are able to answer } \\
\text { questions with the information } \\
\text { explicitly stated in the text }\end{array}$ & $\begin{array}{l}\text { Jelaskan apa yang dimaksud dengan proses ekspirasi! (explain } \\
\text { the process of expiration!) }\end{array}$ & & & & \\
\hline 5 & $\begin{array}{l}\text { Students are able to mention } \\
\text { kewords found in the text. }\end{array}$ & $\begin{array}{l}\text { Cari kata kunci dari paragraf } 2 \text { dan paragraf } 5 \text { !(find out } \\
\text { keywords in paragraph two and three!) }\end{array}$ & & & & \\
\hline 6 & $\begin{array}{l}\text { Student are able to retell the } \\
\text { content of the text using their } \\
\text { own words }\end{array}$ & $\begin{array}{l}\text { Ceritakan kembali isi teks yang telah kamu baca dengan kata- } \\
\text { katamu sendiri!(retell the content of the text using your own } \\
\text { words!) }\end{array}$ & & & & \\
\hline 7 & $\begin{array}{l}\text { Students are able to infer the } \\
\text { content of the text. }\end{array}$ & $\begin{array}{l}\text { Simpulkan isi teks yang telah kamu baca!(summarize the text } \\
\text { you read!) }\end{array}$ & & & & \\
\hline 8 & $\begin{array}{l}\text { Students are able to } \\
\text { differentiate between sentence } \\
\text { containing fact and sentence } \\
\text { containing opinion. }\end{array}$ & Tuliskan salah satu kalimat yang termasuk fakta pada paragraf 4 ! & & & & \\
\hline 9 & $\begin{array}{l}\text { Students are able to draw } \\
\text { mapping for the concept } \\
\text { discussed in the text. }\end{array}$ & $\begin{array}{l}\text { Buatlah peta konsep dari teks yang kamu baca! (draw concept } \\
\text { mapping from the text you read!) }\end{array}$ & & & & \\
\hline 10 & $\begin{array}{l}\text { Students are able to understand } \\
\text { the writer's message as part of } \\
\text { the reading comprehension } \\
\text { toward the text. }\end{array}$ & $\begin{array}{l}\text { Manfaat apakah yang dapat diambil dari informasi dalam teks } \\
\text { yang telah kamu baca? (what benefit do you get from reading the } \\
\text { text?) } \\
\text { Apabila di lingkungan rumahmu terjadi pencemaran udara maka } \\
\text { apa yang akan kamu lakukan? Tulislah rencanamu untuk } \\
\text { mencegah pencemaran udara tersebut! (if air pollution happens } \\
\text { in your environment, what will you do? Write your plans to avoid } \\
\text { and solve air pollution problem?) }\end{array}$ & & & & \\
\hline
\end{tabular}

Instrument test validity for ITIWM was ensured using content validity. The validity of the test instrument was obtained through the preparation of the instrument clues or hints. To ensure the content validity, expert judgment on lesson plans, learning model and media was applied. This study used categorical judgment. It meant that the expert was given statements and they valued these statements. The validity level of the research instrument was generated from expert's judgment. The formula for descriptive level of validity analysis is as follows

$\mathrm{Va}=\mathrm{TSe} / \mathrm{TSh} \mathrm{X} 100 \%$

Explanation:

Va: Expert validation

TSe: empirical total score (result of validation from experts)

TSh: expected score total

In terms of validity measurement, the following criteria were used:

$85,01 \%-100,00 \%$ : Very valid, applicable without revision.

Anatolian Journal of Education, October $2020 \bullet$ Vol.5, No.2 


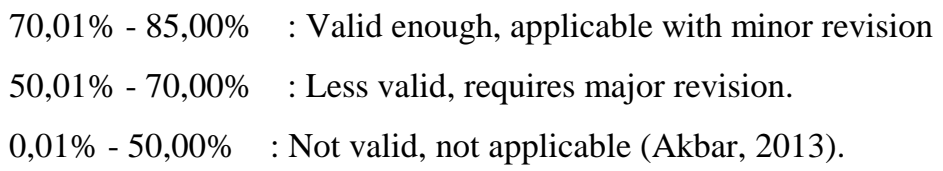

Item validity for reading comprehension used in this study was tested using Pearson Product Moment, followed by counting t observed.

To ensure validity of each item in the test, this study applied Pearson product moment correlation then calculated using t test. This can be seen in the following table:

Table 3

Result of Instrument Validity Test for Reading Comprehension

\begin{tabular}{lllll}
\hline No Item & $\mathrm{t}_{\text {hitung }}$ & $\mathrm{t}_{\text {table }}$ & & explanation \\
\hline 1. & 0,399 & 0,444 & Valid & Used \\
2. & 0,433 & 0,444 & Valid & Used \\
3. & 0,855 & 0,444 & Valid & Used \\
4. & 0,805 & 0,444 & Valid & Used \\
5. & 0,391 & 0,444 & Valid & Used \\
6. & 0,557 & 0,444 & Valid & Used \\
7. & 0,569 & 0,444 & Valid & Used \\
8. & 0,744 & 0,444 & Valid & Used \\
9. & 0,478 & 0,444 & Valid & Used \\
10. & 0,656 & 0,444 & Valid & Used \\
11. & 0,865 & 0,444 & Valid & Used \\
\hline
\end{tabular}

Based on the data above, it can be seen that item instrument for reading comprehension were classified as valid. There were 11 items. Reliability test used in this study using reliability coefficient technique Alfa Cronbach with alpha $\alpha$ is 0,834 for reading comprehension and it is bigger than 0,05 . Based on this result, the items were categorized as reliable.

\section{Data Analysis}

Data analysis was performed to determine the mean of standard deviation scores on initial and final tests, normality tests, homogeneity tests to show that two or more groups of sample data came from populations having the same variance. In the regression analysis, the required analytical requirement is that the regression error for each grouping based on the dependent variable has the same variance. Homogeneity test was done by comparing the largest variance and the smallest variance by using table. To see improvements in students' reading comprehension before the experiment and after the experiments on the control class and the experimental class were calculated using a normalized gain with the gain level category is if $\mathrm{g}>0.7$, then the significant level of gain is expressed in the high category, if 0.03 for $\mathrm{g} \leq 0.7$ then the gain level is expressed in the medium category and if $\mathrm{g}<0.3$ then the gain level is in the low category. In processing, instrument testing, proving the level of validity and reliability of a measuring instrument or data analysis is the normality and homogeneity test data, also test the difference of two average processed using SPSS version 16.

\section{FINDINGS}

\section{The Effect of ITIWM to Improve SRCIT}

The test was done in two stages: first is pretest. It was given to the both experimental class and control class to determine their initial ability in reading comprehension wheteher they were the same or not. Second is posttest. It was administered to both groups. It was given to find out whether there is an effect of ITIWM on SRCIT. 
In pretest stage, homogeneity and normality test was conducted for both group samples in pretest, normality test used Kolmogorov-Smirnov using the software SPSS version 16. To find out data distribution for pretest score and experiment and control group was conducted using data normality test. The test was done by comparing probability (sig.) with value of alpha $(\alpha)$. Test criteria is (Sig.) $>$ alpha $(\alpha)$, so the test result is considered normal distribution. Normality test using KolmogorovSmirnovis if the number is significant (Sig.) $<0,05$, is considered non-normal distribution, but if the score is significant (Sig.) $>0,05$ is considered normal distribution. After applying normality test, next step was homogeneity test. The criteria of homogeneity test using program SPSS version 16 can be done by comparing score significant (Sig.) with value of alpha $(\alpha)$, with the requirement that if value of significant (Sig) is bigger than $\alpha(0,05)$, the data are considered Homogeny, but id value of significant is smaller than $\alpha(0,05)$, the data are considered not homogenous.

After getting normality and homogeneity of the data, next step was difference test using Independent Sample t-test analysis.

Hypothesis of the test is as follows:

Ho: there is no difference of mean score between control and experiment group

H1: there is a difference of score mean between control and experiment group.

Using the criteria test, if the score of $\mathrm{p}>0,05$, the hypothesis $\mathrm{H} 0$ is accepted and $\mathrm{H} 1$ is rejected. To test significance level, it can be done by comparing between probability sig. With the value of alpha $(\alpha)$. If probability value $>$ value $\alpha$, it is considered not significant. In contrast, if value of probability sig. $<$ value $\alpha$, it is considered significant. Test result using t-test can be seen in the following table:

Table 4

Result of Difference Test for Pre-Test for Reading Comprehension of Experiment Class and Control Class for School with Easy Access of Information

\begin{tabular}{llllll}
\hline Data & $\mathrm{t}_{\text {hitung }}$ & $\mathrm{df}$ & $\mathrm{t}_{\text {table }}$ & sig. & Decision \\
\hline Pre-test eks_control1 & 0,423 & 55 & 1,325 & 0.674 & No difference \\
Pre-test eks_control2 & $-0,407$ & 59 & 1,425 & 0.686 & No difference \\
Pre-test eks_control3 & 0,414 & 57 & 1,375 & 0,680 & No difference \\
\hline
\end{tabular}

Table 5

Result of Difference Test for Reading Comprehension for Experiment Classes and Control Group among Schools with Medium Access of Information

\begin{tabular}{llllll}
\hline Data & $\mathrm{t}_{\text {hitung }}$ & $\mathrm{df}$ & $\mathrm{t}_{\text {table }}$ & sig. & Keputusan \\
\hline Pre-test eks_control1 & 0.000 & 78 & 1,9 & 1.000 & No difference \\
\hline Pre-test eks_control2 & 0,438 & 78 & 1,9 & 0,663 & No difference \\
\hline Pre-test eks_control3 & 1,105 & 78 & 1,9 & 0,273 & No difference \\
\hline
\end{tabular}

Table 6

Result of Difference Test for Reading Comprehension for Experiment Class and Control Class with School with Difficult Access of Information

\begin{tabular}{llllll}
\hline Data & $\mathrm{t}_{\text {hitung }}$ & $\mathrm{df}$ & $\mathrm{t}_{\text {table }}$ & sig. & Keputusan \\
\hline Pre-test eks_control1 & $-1,113$ & 70 & 1,7 & 0,261 & No difference \\
Pre-test eks_control2 & $-0,089$ & 66 & 1,6 & 0,929 & No difference \\
Pre-test eks_control3 & $-3,613$ & 53 & 1,275 & 0,010 & No difference \\
\hline
\end{tabular}

Based on the above tables, it can be seen that difference test for mean and posttest for reading comprehension skill between experiment and control class in group two at the level of significance 0,05 is gaining p (sig. (2-tailed) $=0,261,0,929$. $\mathrm{T}$ table can be achieved using distributed $\mathrm{t}$ with the 
degree of validity $95 \%(\alpha=5 \%$, since $t$ test is two sides in nature, then the value $\alpha / 2=5 \%=0,025)$ with the degree of freedom $(\mathrm{df})=\mathrm{n}-2$, referring to $\mathrm{t}$ table $=\mathrm{t}(0,025)$.

because $\mathrm{p}>0,005$, then $\mathrm{H} 0$ is accepted and $\mathrm{H} 1$ is rejected, or if the mean of the two groups are the same. The decision is made by comparing t observed and t tabel, with the following criteria:

If $\mathrm{t}$ observed <t_table, $\mathrm{H} 0$ is accepted and $\mathrm{H} 1$ is rejected.

If $\mathrm{t}$ observed >t_table, $\mathrm{H} 0$ is rejected and $\mathrm{H} 1$ is accepted.

$\mathrm{t}$ _observed $<\mathrm{t}$ _table or fall into the area of rejection $\mathrm{H} 0$ can be decided that $\mathrm{H} 1$ is rejected and $\mathrm{H} 0$ is accepted. Therefore, it can be concluded that there is no difference between mean of pretest for experiment and control class in reading comprehension with the degree of certainty $95 \%$.

For posttest result, it can be seen in the following table:

Table 7

Result of Difference Test for Reading Comprehension for Experiment and Control Class with Easy Access of Information

\begin{tabular}{llllll}
\hline Data & $\mathrm{t}_{\text {hitung }}$ & $\mathrm{df}$ & $\mathrm{t}_{\text {table }}$ & sig. & decision \\
\hline Pre-test eks_control1 & 7,643 & 59 & 1,425 & 0,000 & No difference \\
Pre-test eks_control2 & 6,213 & 57 & 1,375 & 0,000 & No difference \\
Pre-test eks_control3 & 6.087 & 55 & 1,325 & 0,000 & No difference \\
\hline
\end{tabular}

Table 8

Difference Test Result for Reading Comprehension between Experiment and Control Class for School with Medium Access of Information

\begin{tabular}{llllll}
\hline Data & $\mathrm{t}_{\text {hitung }}$ & $\mathrm{df}$ & $\mathrm{t}_{\text {table }}$ & sig. & decision \\
\hline Pre-test eks_control1 & 5,490 & 77 & 1,875 & 0,000 & No differencce \\
Pre-test eks_control2 & 6,204 & 71 & 1,725 & 0,000 & No difference \\
Pre-test eks_control3 & 6,937 & 75 & 1,825 & 0,000 & No difference \\
\hline
\end{tabular}

Table 9

Result of Difference Test for Reading Comprehension between Experiment and Control Class for Schools with Difficult Access of Information

\begin{tabular}{llllll}
\hline Data & $\mathrm{t}_{\text {hitung }}$ & $\mathrm{df}$ & $\mathrm{t}_{\text {table }}$ & sig. & decision \\
\hline Pre-test eks_control1 & 10,970 & 70 & 1,7 & 0,000 & No difference \\
Pre-test eks_control2 & 5,650 & 66 & 1,6 & 0,000 & No difference \\
Pre test eks_control3 & 3,837 & 53 & 1,275 & 0,000 & No difference \\
\hline
\end{tabular}

From the tables above, it can be seen that difference test for posttest on reading comprehension for experiment and control class with the degree of significance 0,05 is gaining p (sig. (2-tailed) $=0,000$. $\mathrm{T}$ table can be gained through distribution table $t$ with the degree of certainty $95 \%(\alpha=5 \%$, because $t$ test has two sides, the value $\alpha / 2=5 \%=0,025)$ and degree of freedom $(\mathrm{df})=\mathrm{n}-2$, with $\mathrm{t}$ table $=\mathrm{t}(0,025)$.

With $\mathrm{p}<0,005$, therefore $\mathrm{H} 1$ is accepted and H0 is rejected, or both mean has a difference. The decision is made by comparing the value t observed and $\mathrm{t}$ table, with the following conditions:

If $\mathrm{t} \_$observed <t_table, $\mathrm{H} 0$ is accepted $\mathrm{H} 1$ is rejected.

If $\mathrm{t} \_$observed $>\mathrm{t}$ _table, $\mathrm{H} 0$ is accepted dan $\mathrm{H} 1$ is accepted.

t_observed $>\mathrm{t}$ _table or it belongs in the area or rejection $\mathrm{H} 0$ then it was decided that $\mathrm{H} 0$ was rejected and $\mathrm{H} 1$ was accepted. It can be concluded that there were significant differences between mean of scores of posttests for experiment and control class in reading comprehension with the level of degree of certainty $95 \%$. 
Explanation concerning group three: For experiment class, this study used students in SDN Warungcaringin because there was a suggestion from local government office for education. The sample was taken for control class from other school.

The above table explains that experimental class group 1, group 2 and group 3 had an increase in each indicator for reading comprehension compared to their previous reading comprehension ability. understanding. However, their increase varies and they can be seen in the percentage of their increase (gain) in reading comprehension for the text after they learned using ITIWM. A substantial percentage increase was achieved by first experimental group, that is a category of elementary schools with easy access to information. The increase also occurred elementary schools in groups two and three. The third group's increase was smaller than groups one and two and It belongs to category of school with a difficult access to information. Unlike group one and three, group two is school with category of medium ease of access to information. In terms of reading comprehension indicator, the greatest increase occurred in students' ability to distinguish fact from opinion. This happened in all groups. The lowest increase appears on the fourth indicator that is students' ability to answer questions whose answer is explicitly stated in the text. Their increase in reading comprehension ability is low because the result of their pretest had shown high points and students were considered competent enough.

Based on the findings of the study, it can be seen that that there is an effect of ITIWM on SRCIT in 5 th grade elementary schools in Bandung regency. Speaking of results, ITIWM implementation has generated varied effect. This is to say that SRCIT of each group yielded different results.

\section{The Implementation of ITIWM to Improve SRCIT}

Based on the observation, this study found several things throughout the implementation of ITIWM. In the beginning, the teacher greeted and invited all students to pray according to their respective religion and belief. He checked students' readiness by filling out their attendance sheets and checking their clothes, positions and seating. Next, he communicated to the student the activities to be performed. In this occasion students listened to the teacher's introductory story on the "Human Body Organ Function" text to stimulate them to share their personal experiences related to the text. Stimulating students was done by asking them to brainstorm parts of the human organs and their functions. There are several activities that can stimulate students to increase their reading comprehension concerning the text they are studying. In order for students to understand the texts they are about to read; students should be invited to engage in a learning activity that can invite students to relate their experiences to the content of the text. If prior knowledge has been activated early before reading activity, student will no longer depend on the vocabulary found in the text for their reading comprehension.

In reading activity, there are many strategies that can be used to boost comprehension. One of the strategies is brainstorming. It aims to activate readers' knowledge. It can be deployed by the teacher at the beginning of reading activities in order to gather ideas and opinions to answer specific questions. It allows a number of opinions or ideas to occur from student's prior knowledge. In line with this, Wallace (1992: 91) writes that one of the popular early reading techniques used was brainstorming. Brainstorming has several advantages to offer. These advantages include: providing teachers with little preparation; allowing students to freely express their initial knowledge and ideas to integrate with the theme to be learned on that day, involving students to fully participate in learning activities.

Besides brainstorming, there is semantic mapping activity. It aims to classify all information generated by students concerning the content of the text. It followed by discussion to analyze the vocabulary that students had expressed in brainstorming session. These vocabularies and information can be classified to several categories relevant to the content of the text. In this occasion, teachers are in the position to explain all aspects of language on the vocabulary and information that students gathered.

Anatolian Journal of Education, October $2020 \bullet$ Vol.5, No.2 
After conducting the previous steps, the teacher had several steps left to be accomplished. He wrote students' experiences on the board. Under teacher's guidance, students rewrote their experiences related the function of human organs by filling in students' Worksheet available in column 1. They observed images of human organs expected to stimulate them to know every part of their bodies. They wrote their observation questions on the Student Worksheet in column 2 with teacher guidance. These initial activities were expected to: boost students' interest in the topic of reading, cultivate their meticulous and careful attitude in observations, train their skills in writing information from observations and personal experiences.

In the core activities, students were assigned to read the text "Function of Human Body Organs". They read the text at a glance to look and search for important information namely keywords and main ideas. Furthermore, they were assigned to dig information by reading quickly in order to seek important information from each paragraph, distinguish facts from opinions in each paragraph of the text. They rewrote important information from the by filling in the Student Worksheet in column 3 with teacher guidance. They also wrote questions related to the text "Function of Human Body Organs" on the Student Worksheet in column 3 with teacher guidance. The teacher activated students' initial knowledge by asking them to demonstrate what they knew. They collaborated either as a class unit or in small groups to set their goals and decide what they wanted to learn. After reading activity they discussed what they had learned. Next, they applied a higher order thinking to facilitate them to build meaning from what they read and to help them monitor their progress toward the goal of thinking. They need guidance on strategies to help them focus on reading and understanding more the content on the text. In this part, they need their teacher to play role as model to teach them how to use various reading strategies that will help them to become self-sufficient readers.

To evaluate learning effectiveness, the teacher compared students' scores on comprehension questions, student worksheets and reading tests before and after the implementation of these ITIWM interventions. This strategy led students to read quietly for comprehension purpose. In addition, they connected new information with what they already knew when they confirmed or disconfirmed information in column one. Next, students learned to set their own goals for reading when they were generating questions for column two. They read to answer these questions and this condition helped them concentrate because they were more active in monitoring their own comprehension. Column three gave students the opportunity to summarize what they were reading. When they paraphrased information in their own words, they would better understand what they already knew and did not. This helped them to move on to the next step which generated more questions and used more learning resources. Having done previous steps they prepared for a publication step that is they organized information and wrote it for presentations to others. These steps reinforced their information comprehension, their effort to be good readers and their process to perform self-reading (Lenski, 2004; Jonson, 2007).

The next step was the teacher and student discussed questions written on the Student Worksheet in column three. They worked on issues related to the text "Function of the Human Body Organs". This was done to measure students' comprehension on the text they were reading. In order to achieve deeper comprehension, he divided them into five groups and they were assigned to read additional books related to the function of human organs. Furthermore, they were assigned to write a resume from the books they read. They presented their work in front of the classroom and they responded orally to questions posed by the teacher. The expected outcomes to achieve in the core activities were: their knowledge on the human organs and their functions, their ability to comprehend text by searching for important information, their ability to comprehend text by digging information from the text, their ability to paraphrase the results of the reading comprehension, their expected condition as independent reader. 
In the final activity, the teacher concluded the learning outcomes by re-explaining the discussion related to the text "Human Body Organ Function". He provided reinforcement to students on how to maintain their organs health. He encouraged them to be diligent in reading and keep reading various books. Furthermore, he gave them task to be done at home. The task required them to make a report related to how to maintain a healthy body and how to maintain the health of the home environment. He closed learning activity by praying and saying goodbye. The expected outcome of closing activities was that they would be motivated to diligently read informational texts related to any topic to gain broader knowledge.

\section{DISCUSSION}

Description on students' reading comprehension skill can be taken from observation and interview to the teacher of grade 5 involving in this study. The teachers taught in several schools located in Bandung regency. The results show that students' reading skill were at the level 2 which was under the level of minimum achievement for students to accomplish that is 75 point. Based on this data, there is a need to solve this problem. Students' reading comprehension skill must be improved otherwise their poor performance would be a barrier for them to proceed in the next grade. The analysis section shows that almost $80 \%$ of the students could remember explicit meaning from the text. For example, students were able to recognize explicit meaning in terms of mentioning the functions of parts of the body both in written and spoken form. They were able to mention the process of water recycle both in written and spoken form. Example two, students were able to recall explicit meaning by identifying picture of human part of the body and identifying the picture of water recycle. This has shown that students had good enough reading comprehension. In terms of understanding the content by summarizing the text, student had a poor competence in reading comprehension. For example, they found difficulty to decide main idea of a particular paragraph and recognizing the keywords found in a paragraph. In spotting the keywords found in paragraph, students scored very low because they did not know how to decide the keywords from a paragraph. Regarding the competence to explain using own words, student had exhibited poor competence. They lacked of competence to explain information from text using their own words. Instead using their own words, they cited word from the text to try to explain the information from text. but they did not use their own words. Many of them struggled to analyses information and describe information from the text in terms of image, text and a collection of data. For example, they had poor competence to describe information from text in a written conceptual mapping. Many students were not able to find explicit meaning from the text

ITIWM to improve SRCIT was proven to be effective. This was achieved by the supporting factor namely teacher's role in guiding every step of reading comprehension on informational text. To improve SRCIT the teacher should be able to facilitate the students to actively construct their knowledge. He must have a special learning model that is able to make them become active and independent readers. The learning model should embrace an active, creative and fun learning process. The learning process will trigger students to think uniquely to analyze and to solve problems in making decisions (Iskandarwassid \& Sunendar, 2011).

The implementation of ITIWM illustrates in general that the learning process of reading comprehension was done in a systematic step in order to achieve the learning objectives. The results obtained from the trial test show that there is a difference in the ability of the 5th grade students of elementary school before and after the use of ITIWM. This is evidenced by the t-test results on the gain of $\mathrm{p}$ (sig. (2-tailed) $=0,000$ This means there is a significant increase. It should be noted that the improvement varies in each group and it depends on some very important factors.

There are several factors contributing to the increase of SRCIT. first factor was the teacher's ability to stimulate and convey information in the learning process so that the information became meaningful for students. Second factor is the ease of access to information. It has something to do with the 
availability of textbooks and supporting books that students can read at school. Third factor is parental guidance. Their role is crucial in providing literacy artifacts at home to support their children reading activity (Mustafa, 2014). Fourth factor is students' basic knowledge as a prerequisite before they deal with the text they read.

The schools' facilities and infrastructure also greatly affected the SRCIT. For example, a school with a complete library will enable students to have good reading comprehension. In this study, a high increase was obtained by schools with easy access to information (group one). This happened because of the important supporting factors mentioned above. It goes without saying that Teacher performance, comfortable school situation and situation, provision of school facilities and infrastructure and parental support played a great role to increase SRCIT. Students in the school with medium access to information (group two) and students placed in school with difficult access to information (group three) had improved their reading comprehension capability but their improvement was smaller compared to that obtained by their counterparts in group one that is school with easy access to information.

SRCIT was also supported by active learning and teacher modelling. These factors helped students to move to the higher level. This is to say that they left their traditional roles as passive receptors and went forward to learn and practice how to capture knowledge and skills to make their learning meaningful. In addition, access to information played pivotal role to increase SRCIT. The above explanation indicates that the ease of access to information greatly affects students' reading comprehension ability. In this study, access to information is defined broadly including from electronic media, internet access and printed media like reading books for students. Those information access broadened their knowledge and prepared them well to participate in reading class.

In teaching informational text reading comprehension, the teacher should follow syntax of teaching and learning. He should guide the students from the first step to the last step. He should motivate students to build their own knowledge in many ways to make information meaningful and highly relevant to them. They should be given opportunity to discover or apply their own ideas and to encourage them to realize and use their strategies to learn. In this study, the basic knowledge of the students, the availability of textbooks and reading books support for students both at school and at home greatly affect the increase of SRCIT.

The implementation of ITIWM should be assisted by several factors namely teacher performance, supporting books and parental guidance. These factors contribute significantly to students to achieve the goal of learning. in line with this Mustafa (2014), Schugar \& Dreher (2017) pay great attention on the importance of a literate environment for the development of children's literacy. In this study some parents were trying to create literacy practices for their children. Some are successful and some are not in providing literacy support for their children. Their support can be in the form of concrete literacy practices or the provision of artifacts and a supportive atmosphere. The literacy gap among students in this study existed due to the diversity of literacy backgrounds from their home. This is to say that the school consisted of both students coming from the literate rich neighborhoods and those coming from disadvantaged families.

This study found some interesting facts concerning students' knowledge and their literacy support at home. Some students understood easily informational text and some of them were happy to learn through exercises without assistance from others. There were also students who were accustomed to reading the text of information in the newspaper or in his father's reading books. As the result they were active when learning in the classroom. There were some students who had been able to criticize the teaching materials used in this study. They advised that the words in the teaching materials should not be too difficult to understand. Most of them felt happy learning to read informational text and dealt with the questions available in the Student Worksheet. In their opinion, Student Worksheet helped

Anatolian Journal of Education, October $2020 \bullet$ Vol.5, No.2 
them to be more focused in reading comprehension activity. This circumstance suggests that students already had the ability to analyze and synthesize their initial knowledge with new knowledge they gain in reading.

In a school, this study found student who already had reading appreciation. He was able to distinguish genre types and articulate his own response to the author's intent. Since he often read either textbooks or literary books, he was able to perform the aforementioned skills. Readers' ability to understand reading material depends on how they view the text. This perception can be based on previous experience or encounter with the word or idea of Mirasol, (2015). Reading activity should apply interactive activities to boost students reading comprehension. In the same vein, Joseph (2015) found that interactive activities will be useful to change meaning by involving students in strategic steps during learning. Interactive activities refer to activities that require high student participation rates and they can be in form of group activities, discussion and retelling. Teachers guide students to perform different learning tasks at different levels of interaction. In essence, students learn about the mental processes involved in activating ideas and making connections between new and known ideas. This strategy makes the students aware that three different types of meaning can occur that are constructed while reading that is literal, inferential and personal. They develop an understanding that previous reader knowledge plays an important role in constructing meaning and some meanings exist around the text.

Unlike good performers in group one, group three obtained the lowest increase in SRCIT. Being in the schools with difficult category of access to information, the students' performance could not excel their counterpart from group one. Difficult access to information positioned school with lack availability for reading activities for students. The students had less initial knowledge because of the unavailability of books containing the text of information to be read in their school. furthermore, students were not provided supporting books in their homes. Instead of reading book they listened more to the tale delivered by their father or grandfather. The unavailability of textbooks and related supporting books greatly affected SRCIT. This school condition can be associated with low reading motivation. In several studies (Juel, 1988; Kamgar, et.al., 2016), it was found that 40 percent of poor reader problems refer to lack of reading motivation (Maftoon \& Tasnimi, 2013; Kamgar, et.al., 2016.) They suggested teachers should have more strategies in teaching reading skills to improve students' motivation and they need their teachers to serve as models. These two factors assist them to be able to learn by themselves, and develop their autonomy in reading activity. Other aspect to take into account is learning environment such as the provision of learning media and a pleasant learning sheet.

\section{CONCLUSION}

This study was aimed at investigating the effect of ITIWM to improve SRCIT and it also explored the implementation of ITIWM in reading comprehension classes for 5th grade elementary schools in Bandung regency. Based on the results and findings in the study, it can be concluded that ITIWM was proven to have a significant influence on SRCIT of the 5th grade students in Bandung Regency. However, this increase was strongly influenced by various factors such as teacher performance, availability of supporting books at school and at home, parental capacity to provide literacy artifacts at home. This research was aimed at activating students to learn from the text. Their experiences in reading comprehension activity is expected to boost their knowledge, to share their knowledge with others and to be able to apply their experiences in daily life.

Based on the findings of the study, it is suggested that schools should provide students with literary artifacts to enrich their knowledge. In this case the school must bridge the knowledge gap that the students have by creating a special program to train students' habits in reading the books supporting subjects. In addition, the school should facilitate teachers to conduct book reviews with a minimum of two-week meeting. This can serve as an effort to increase their insight and improve their 
professionalism. Schools should also be able to involve parents in administering several programs like providing supporting books and modifying the corners of the class into a reading corner. This is important as part of the school's efforts to raise their awareness in providing literacy tools for their children at home as one of the efforts to support their children's success in learning.

This study has several limitations. Further study needs to be conducted by refining the use curriculum design with other models, the use of different text types, administering more interesting student activities.

\section{REFERENCES}

Croce, A. K. (2014). Assessment of burmese refugee students' meaning making of scientific informational texts. Journal of Early Childhood Literacy, 14(3), 389-424.

Forgaty, R. (1991). The mindful school. How to integrate the curricula. USA: IRI/Skylight Publishing.

Fox, E. (2009). The role of reader characteristics in processing and learning from informational text. Review of Educational Research Spring, 79(1), 197-261.

Gunobgunob-Mirasol, R. (2015). The relative effect of glossing instruction college students' reading comprehension. Procedia - Social and Behavioral Sciences, 208, 82-90.

Hamra, A., \& Syatriana, E. (2012). A model of reading teaching for university efl students: Need analysis and model design. English Language Teaching, 5(10), 1-11.

Hermawanti, A. S., Al-Rasyid, H., \& Mujtahidin. (2015). Efektivitas Pembelajaran Tematik ditinjau dari Kemampuan Guru Merencanakan dan Melaksanakan Pembelajaran di Kelas 5 SD Muhammdiyah 8 Kecamatan Tulangan Tahun 2015. Jurnal Widyagogik, 3(1), 79-89.

Iskandarwassid\&Sunendar, Dadang. (2011). Strategi Pembelajaran Bahasa. Bandung: Remaja Rosdakarya.

Jennings, J. H., Caldwell, J. S., \& Lernler, J. W. (2006). Reading problems: Assessment and teaching strategies. Boston: Pearson.

Jonson, K. F. (2007). 60 Strategies for improving reading comprehension in years $P-8$. Corwin.

Kadir, A., \& Ashrohah, H. (2015). Pembelajaran Tematik. Jakarta: Raja Grafindo Persada.

Kamgar, N., \& Jadidi, E. (2016). Exploring the relationship of Iranian EFL learners' critical thinking and self-regulation with their reading comprehension ability. Procedia - Social and Behavioral Sciences, 232, 776-783.

Kovalik, S., \& Olsen, K. (1994). ITI: The model. Integrated thematic instruction. 3rd ed. Kent. Wash.: Books for Educators.

Kristiantari, R. (2014). Analisis Kesiapan Guru SD dalam Mengimplementasikan Pembelajaran Tematik-Integratif Menyongsong Kurtilas. Jurnal Pendidikan Indonesia, 3(2), 460-471.

Masdiana, M., Budiarsa, I. M., \& Lamba, H. A. (2014). Penerapan Pembelajaran Tematik untuk Meningkatkan Hasil Belajar IPA Materi pada Lingkungan Siswa Kecamatan Mamuju Utara. Jurnal Kreatif Tadulako, 3(2), 190-204.

Meyer, C., \& Jones, T. B. (1993). Promoting active learning: Strategies for collage classroom. New York: Maxwell Macmillan. 
Munawaroh, I. (2010). Pengembangan Model Pembelajaran Tematik untuk Mengembangkan Keterampilan Berpikir Kritis Siswa SD Kelas Rendah. Jurnal Penelitian Ilmu Pendidikan, 3(1), 4660.

Musthafa, B. (1996). Learning from text and reading instruction. ERIC. ED.395268 (1996), pg.45.

Musthafa, B. (2014). Literasi Dini dan Literasi Remaja: Teori, Konsep dan Praktik. Bandung: CREST.

OECD. (2016). PISA 2015 Assessment and Analytical Framework: Science, Reading, Mathematic, and Financial Literacy. Paris: OECD Publishing.

Pusat Pengembangan Tenaga Kependidikan Kemdikbud 2013.

Puspita, R. D. (2017). Pengembangan Perangkat Pembelajaran Tematik Terpadu Berbasis Model Interactive Compensatory untuk Meningkatkan Kemampuan Membaca Pemahaman Teks Informasi. Bandung: UPI.

Puspita, R. D., Sunendar, D., Musthafa, B., \& Yudiantara, R. A. (2017). The use of interactivecompensatory model based-learning material to improve informational text reading comprehension ability of 5th grader elementary school In Bandung Regency, Indonesia. Advance Science Letters, 23(11), 10952-10954.

Sahin, A. (2013). The effect of text types on reading comprehension. Mevlana International Journal of Education, 3(2), 57-67.

Schugar, H. R., \& Dreher, M. J. (2017). U.S. fourth graders' informational text comprehension: Indicators from NAEP. International Electronic Journal of Elementary Education, 9(3), 523-552.

Setiawan, H., Sa'dijah, C., \& Akbar, S. (2017). Pengembangan Instrumen Asesmen Autentik Kompetensi pada Ranah Keterampilan untuk Pembelajaran Tematik. Jurnal Pendidikan: Teori, Penelitian dan Pengembangan, 2(7), 874-882.

Sulak, S. E., \& Güneş, F. (2017). The effects of teaching informative text through processual model on reading compression skills. International Electronic Journal of Elementary Education, 10(2), 265271.

Wallace, C. (1992). Reading. Oxford: Oxford University Press.

Walters, B., \& Barbara A. (2014). Informational text and the common core: A content analysis of three basal reading programs. SAGE, 4(4), 1-8.

Waridah, A. (2016). Pengembangan Perangkat Pembelajaran Tematik-Integratif Tema Menghargai Jasa Pahlawan Berbasis Sosiokultural di SD. Jurnal Prima Edukasia, 3(2), 213-226.

Yochum, N. (1991). Children's learning from informational text: The relationship between prior knowledge and text structure. Journal of Literacy Research, 23(1), 87-108.

Yusuf, H. O. (2015) Interactive activities and its impact on students' performance in reading comprehension in senior secondary schools in Kaduna Nigeria. Procedia - Social and Behavioral Sciences, 174, 523-528. 